\title{
Biomarkers for determination prostate cancer: implication for diagnosis and prognosis
}

\section{Minireview}

\author{
S. ZIARAN ${ }^{1}$, Z. VARCHULOVA NOVAKOVA ${ }^{2}$, D. BOHMER ${ }^{2}$, L. DANISOVIC $2, *$
}

${ }^{1}$ Department of Urology with Centre for Kidney Transplantation, ${ }^{2}$ Institute of Medical Biology, Genetics and Clinical Genetics, Faculty of Medicine and University Hospital, Comenius University in Bratislava, Sasinkova 4, 81108 Bratislava, Slovak Republic

*Correspondence: lubos.danisovic@fmed.uniba.sk

Received December 29, 2014 / Accepted April 21, 2015

\begin{abstract}
Prostate cancer (PCa) belongs to most common cancers and it is the second leading cause of cancer death in men. A genetic predisposition or acquired genetic and epigenetic changes with effect of other factors, such as advanced age, race and environmental factors contribute to PCa development. PCa is a very heterogeneous disease that is characterized by different clinical behavior, from indolent, slow-growing tumors to aggressive, fast-growing tumors with lethal progression. Early diagnostics and identification of PCa type are crucial prerequisites for efficient treatment of patients. Recently, the diagnostics of early stages of PCa is based mostly on evaluation of prostate-specific antigen (PSA) in serum of patients. Men with high levels of PSA undergo biopsy in order to determine histopatological grading of PCa - Gleason scoring which classifies tumors from most to least differentiated as well as staging - determination of the status of their primary tumors, with or without lymph node involvement. The results from this screening diagnosis lead into conventional treatment, including radical prostatectomy and brachytherapy. In case of advanced PCa, conventional treatment continues with androgen deprivation therapy. However, in many cases the cancer recurs. Therefore, the clinicians and researchers are forced to find more precise and sensitive biomarker suitable for PCa diagnostics as well as prognostics and therapy. This paper provides review of current most promising molecular and immunohistochemical biomarkers in PCa diagnosis, prognosis and clinical behavior.
\end{abstract}

Key words: prostate cancer, biomarkers, diagnostics, prognostics

Prostate cancer (PCa) is most common non-dermatologic malignancy of men in Western Europe [1]. The clinical behavior of PCa is highly variable. To identify patient subgroups that require less treatment from those that should be targeted with more aggressive therapy is therefore urgently required. Overtreatment of PCa is a particular concern leading to substantial cardiovascular and skeletal morbidity [2-6]. This is typical for many prostrate-specific antigen (PSA) screen-detected cancers, which in the absence of treatment, may never become life threatening, and thus does not require any treatment. Conversely, more conservative approaches to disease detec- tion and management can leave potentially aggressive cancers untreated. Therefore, improved biomarkers are required to allow radical therapies to be targeted to men with potentially lethal cancers, so that the others, with more benign-behaving indolent cancers, are spared inappropriate treatment.

Current „traditional“ clinico-pathologic prognostic markers predictive of outcome in men with PCs after radical retropubic prostatectomy (RRP) consist of Gleason score, TNM stage, surgical margin status, and preoperative serum PSA [7-10]. Beyond the current clinico-pathologic parameters, there have been other biomarkers and approaches proposed to: (i) distin- 
guish between indolent and potentially life threatening disease (ii) aid the decision for re-biopsy in previous negative biopsies with rising PSA, (iii) monitor the disease progression and its responsiveness to therapy. These approaches and markers include genome-wide association studies (GWAS), chromosomal aberrations, DNA-based markers, RNA-based biomarkers, and protein markers (tissue, serum, urine biomarkers) [11]. Available methods to identify potential biomarkers include genomics, proteomics and tissue based immunohistochemical staining. Quantification of cancer biomarker transcripts using real-time quantitative polymerase chain reaction (qRT-PCR) of large samples may help in the search for clinically useful cancer biomarkers that can be integrated into clinical trial design [12]. Gene expression array technology applied to PCa has resulted in the identification of a number of genes that have been associated with outcome. More recently, next-generation sequencing (NGS) have been described, which could bring promising information in our understanding of the cancer genome of several tumor types [13].

The present paper provides review of current most promising molecular and immunohistochemical biomarkers in PCa diagnosis, prognosis and clinical behavior.

\section{Genetics and epigenetics of prostate cancer}

Initiation of $\mathrm{PCa}$ is a process resulting from the progressive accumulation of genetic disorders [14]. On the basis of the constellation of polymorphisms of germ cell cancer the risk of developing cancer is individual [15]. The cumulative effect of polymorphism genome may lead to one or more disorders, and / or may "offer" an environment for further genetic alterations in prostate epithelial cells. Over time, additional somatic genetic disorders alter the behavior of prostate epithelial cells until it represents signs of malignancy [16]. Epigenetic alterations are other common events in carcinogenesis, including PCa, which may lead to aberrant expression of critical genes such as tumor suppressors and oncogenes. Although most PCa are classified into a single group of adenocarcinomas, there is no univer-

Tbale 1. Overview of the most promising biomarkers used for PCa diagnosis, prognosis and progression.

\begin{tabular}{lll}
\hline Type & Biomarker & Usage \\
\hline DNA-based & GSTP1 & PCa diagnosis \\
& RASSF1A & PCa prognosis and progression \\
& APC & PCa diagnosis \\
& NKX3.1 & PCa diagnosis \\
RNA-based & PCA3 & PCa diagnosis \\
& TMPRSS2 & PCa prognosis and progression \\
ERG & PCa diagnosis & \\
Protein-based & SPINK1 & PCa diagnosis \\
& AMACR & PCa diagnosis \\
& DAB2IP & PCa diagnosis \\
& PCA & PCa diagnosis \\
\hline
\end{tabular}

sal molecular path of PCa development. It is also unlikely that two prostate adenocarcinomas share the same genetic path in the development of cancer. Genetic and genomic technologies have helped to clarify the changes in genes that lead to the development of $\mathrm{PCa}$. These changes provide a molecular basis from which diagnostic, prognostic and predictive biomarkers can be developed [17]. For genetically determined diseases, genetic alterations can be identified by methods of molecular genetics (e.g. polymerase chain reaction, fluorescence in situ hybridisation, genome sequention etc.). These alterations, when identified, can be in turn used as biomarkers for prognosis of PCa and other cancers.

\section{Criteria for a candidate biomarker}

The National Cancer Institute defines a biomarker as "a biological molecule found in blood, other body fluids, or tissues that is a sign of a normal or abnormal process or of a condition or disease." A biomarker may be objectively measured and evaluated as an indication of normal biologic processes, pathogenic processes, or pharmacologic responses to a particular treatment or condition $[18,19]$. Biomarker is an analyte that signifies the presence or degree of a biological process, which in itself is frequently directly linked to the clinical expressions and result of a particular disease [20]. The selection of a cancer biomarker should have a biological or therapeutic basis or at minimum the biomarker should indicate a reliable correlation with the presence, characteristics, or aggressiveness of the cancer. Also, there should be an evaluation of the strength of the marker in relation to the outcome of the disease, which, together with other factors, should be carried out as an independent predictor in a multivariable assay in the general population [21]. Biomarkers for the diagnosis and prognosis of PCa include DNA-based markers, RNA-based biomarkers, and protein markers (Tab. 1). They may be useful for prognostic purposes in the outcome of diseases, with particular attention on the quantitative biomarkers that demonstrate a relationship with the clinical manifestation of the disease and have an effect on quality of life, risk of complications, or survival. Surrogate biomarkers have a significant function in disease monitoring after accepted treatments are introduced. Surrogates are particularly important for those treatments that are uncommon, such as cases in which the direct study has proved to be very difficult because of the limited number of patients and varying expression of their primary illness or in which the efficiency of the treatment must justify the high cost [20].

\section{Identifying discriminating markers}

With the completion of the Human Genome Project, the publication of the International Haplotype Map Project (a catalog of millions of common single nucleotide polymorphisms, or SNPs, in the human population), and a decrease in the cost of high-throughput genotyping, an unbiased genome-wide search for inherited variants associated with PCa risk has 
become feasible. This approach, called a genome-wide association study (GWAS), scans the entire genome, evaluating common inherited variants (minor allele frequency $>1-5 \%$ in the population) in large numbers of cases and controls [11].

GWAS indicate genetic heterogeneity for the onset of disease with numerous low risk loci described along with two notable high-risk loci at $8 \mathrm{q} 24$ and $7 \mathrm{q} 31$. The linked loci on $8 \mathrm{q} 24$ are located immediately downstream of the MYC gene that is up-regulated in $\mathrm{PCa}[22,23]$.

The Practical consortium recently reported the conclusion of their successive GWAS studies. They evaluated over 500,000 alleles (SNPs) in 3 separate cohorts of cases/controls (up to 30,000 men) [24]. The consortium eventually identified alleles in 7 genomic regions (encompassing 13 genes) that were linked to PCa diagnosis (Tab. 2). The allele penetrance ranged from $6-50 \%$ of the population and each allele altered $\mathrm{PCa}$ risk by $0.35-1.89$ (odds ratio). It is interesting, that the risk markers reside largely in noncoding regions of the genome. The mechanism of inherited risk is therefore not readily apparent and the risk alleles provide an opportunity to gain insight into prostate carcinogenesis. There are several potential mechanisms by which a genetic variant may be associated with altered cancer risk, including: (i) genetic linkage to a coding variant in a cancer-relevant gene (ie, the risk SNP is merely a proxy for the true causal exonic variant that was not tested in the GWAS), (ii) alteration in promoter/enhancer binding sites or chromatin structure affecting expression of adjacent or distant genes, or (iii) change in the expression of noncoding RNAs. There is also a high probability that PCa genes/alleles act cooperatively in the aetiopathogenesis of the disease supporting the notion that it is unlikely that any one biomarker alone is likely to be conclusive in detecting and predicting outcome of cancer [25].

\section{Novel biomarkers for PCa diagnosis}

PCA3 and TMPRSS2: ERG fusion. PCA3 is a noncoding RNA with expression confined to the prostate is highly overexpressed in $95 \%$ of PCa compared with normal or benign hyperplastic prostate tissue [26]. PCA3 has been assayed from urine following prostatic massage in 11 separate clinical studies totalling 2737 men from Western countries with an overall sensitivity of $69 \%$ and specificity of $70 \%$ for men with PCa. The role of PCA3 in clinical practice as a commercially-available test remains uncertain with most advocates indicating a place in patients who have already had TRUS biopsies with a negative result for cancer but in whom PCa remains suspected [27-29].

Detection of the TMPRSS2:ERG fusion in urine has been reported to yield $>90 \%$ specificity and $94 \%$ positive predictive value for PCa detection, although a clinical diagnostic test is not yet available [30]. The combination of urinary PCA3 and TMPRSS2- ERG with serum PSA levels has been reported to improve screening performance compared to PSA alone [31]. Moreover, the recent study indicates that integration of levels TMPRSS2:ERG transcripts in urine, with PCA3-score, androgenic status, genetic status and traditional clinical variables could significantly increase detection of high risk group of PCa patients [32].

Early prostate cancer antigen. Leman et al. [31] reported results on a serum biomarker called early prostate cancer antigen (EPCA) using an antibody assay against the EPCA2.22 epitope. The study involved 385 men and reported a $92 \%$ specificity for healthy men and men with benign prostatic hyperplasia and a $94 \%$ sensitivity for overall PCa detection. In addition, authors indicated that EPCA-2.22 was highly accurate in differentiating between localized and extracapsular disease [33].

SPINK1. SPINK1 (also referred to as TAT1) is a biomarker for PCa that can be detected in prostatic massage urine. SPINK1, a trypsin inhibitor secreted from pancreatic acinar cells, is thought to function in the prevention of trypsin-catalyzed premature activation of zymogens within the pancreas and the pancreatic duct. Mutations of this gene is associated with hereditary pancreatitis and tropical calcific pancreatitis $[34,35]$.

Laxman et al. [36] showed that a multiplexed qPCR assay including SPINK1 in sedimented urine from patients presenting for prostate biopsy or prostatectomy outperformed serum PSA or PCA3 alone. SPINK1 expression in urine is also an independent predictor of biochemical recurrence after resection. On the other hand, recent study concludes that SPINK1 protein expression (evaluated by immunochemistry) may not be a predictor of recurrence or lethal PCa amongst men treated by radical prostatectomy [37].

a-Methylacyl Coenzyme A Racemase (AMACR). AMACR is an enzyme localized to the peroxisome and involved in fat metabolism and has been identified to function as a growth promoter, independent of androgens, in $\mathrm{PCa}[38$, 39]. By using various experimental methods and different PCa specimens, the AMACR gene has been shown to be overexpressed in PCa tissue at the mRNA and protein levels and making it a highly specific tissue biomarker currently used to aid in the pathological diagnosis [40].

When PCa tissues were compared with normal controls, a 9-fold increase in mRNA levels of AMACR was discovered in $88 \%$ of the PCa tissues samples [41]. Immunodetectable serum autoantibodies generated in response to the AMACR tumor-associated antigen may also be useful in preliminary

Tbale 2. Overview of candidate genes linked to PCa diagnosis.

\begin{tabular}{ll}
\hline Locus & Candidate genes \\
\hline $2 \mathrm{p} 21$ & THADA \\
$2 \mathrm{q} 31$ & ITGA6 \\
$4 \mathrm{q} 22$ & PDLIM5 \\
$4 \mathrm{q} 24$ & TET2 \\
$8 \mathrm{q} 21$ & NKX3.1 \\
$11 \mathrm{p} 15$ & IGF2, IGF2AS, INS, TH \\
$22 \mathrm{q} 13$ & TTLL1, BIK, MCAT, PACSIN2 \\
\hline
\end{tabular}


diagnosis, especially if combined with PSA screening. A considerably more enhanced sensitivity and specificity in PCa patients with mid-range PSA levels have been observed with AMACR antibodies than that with PSA. This demonstrates that AMACR can be useful in discriminating control subjects from those with PCa [42]. Interestingly, it has been described, that trifluoroibuprofen, an AMACR inhibitor, reduces cancer cell proliferation and Inhibits in vivo tumor growth in aggressive PCa models [43]. This makes AMACR one of possible therapeutical targets in future.

Glutathione S-transferase P1 (GSTP1). GSTs are a ubiquitous family of multifunctional enzymes that conjugate reactive substrates with reduced glutathione (GSH), and are involved in detoxification. Their role is in protecting the cells from oxidative attack [44]. The GSTP1 gene has been observed to be unmethylated in all normal human tissues and $\mathrm{BPH}$, but hypermethylated in specimens of PCa tissues [45]. GSTP1 has been shown to be acutely sensitive in detecting the presence of prostatic intraepithelial neoplasia and $\mathrm{PCa}$, thereby distinguishing patients with these diseases from patients with BPH [46].

DAB2IP. DAB2 interacting protein (DAB2IP) is a Ras GTPase-activating protein that functions as a tumor suppressor. The human DAB2IP gene is located on chromosome 9q33.1q33.3 [47], and is frequently observed to be down-regulated in PCa cell lines [48]. Studies have shown that loss of expression of DAB2IP may be a result of altered epigenetic regulations, for example DNA methylation and histone modification [49]. The abnormal methylation in the promoter region of the DAB2IP gene has been reported to be responsible for transcriptional silencing and consequently performs a significant function in the progression of PCa [50]. Duggan et al. [51] in their study reported a link between a genetic variation in DAB2IP and the risk of aggressive PCa. This research indicates that DAB2IP protein, after further studies, can potentially be used as a very effective novel biomarker for PCa diagnosis, though larger prospective trials are warranted.

NK3 homeobox 1(NKX3.1) gene. The product of the NKX3.1 gene, which is a prostate restricted homeobox protein that is involved in the regulation of prostate development, is expressed in normal prostate epithelium and is often decreased in PIN lesions and in prostate tumor cells $[52,53]$.

NKX3.1 protein has also been implicated in helping to decrease oxidant genome damage by virtue of its ability to activate expression of genes involved in scavenging oxidant radicals [54]. The fact that NKX3.1 is expressed in most PCa, and not in most other tumor types, suggests that NKX3.1 may be an excellent immunohistochemical marker of PCa [55]. Some studies indicate that the loss of $\mathrm{NKX} 3$ gene leads to poorer prognosis in $\mathrm{PCa}$ [56].

\section{Biomarkers for determining PCa prognosis and progression}

TMPRSS2, ERGand ETV1 fusions, ETS family. Transmembrane protease serine proteinase 2 (TMPRSS2), is an androgen-regulated, type II transmembrane-bound serine protease that is locally expressed in the prostate and overexpressed in neoplastic prostate epithelium. TMPRSS2 was thought to play a possible role in PCa metastasis through the activation of protease-activated receptor-2 (PAR-2) [57]. An extensive study focusing on gene fusion transcripts in $\mathrm{PCa}$ identified the fusion between TMPRSS2 (located at 21q22.3) with the transcription factor genes ERG (21q22.2) and ETV1 (7p21.1) [58]. One TMPRSS2 allele loses its promoter, and one of the ERG alleles gains it, resulting in an over-expression of ETS family members in the cancer cells [59] and consequently tumor progression [60]. TMPRSS2-ERG is the most frequent oncogenic gene fusion rearrangement in PCa [61].

ERG and ETV1 show mutually exclusive over-expression in PCa tissues, suggesting a redundant function in PCa development. In addition, ERG and ETV1 gene fusions have been detected in only a limited number of BPH and High-Grade Prostate Intra-epithelial Neoplasia (HGPIN) lesions, albeit in the absence of ETS up-regulation [62].

ETS fusions are strongly linked with survival when associated with loss of PTEN $(\mathrm{P}<0.001)[63]$ and have been identified in $48 \%$ of men who died of castrate-resistant disease [64].

Loss of PTEN. The PTEN gene on 10q23 is mutated in up to $1 / 3$ of hormone refractory $\mathrm{PCa}$ and homozygous deletions and mutations have been identified in a subset of primary $\mathrm{PCa}$ [65]. Loss of PTEN protein in primary PCa, as determined by immunohistochemistry, correlates with high Gleason score and advanced stage [66]. PTEN is a dual protein and lipid phosphatase that is responsible for dephosphorylation and inactivation of phosphatidylinositol 3,4,5-trisphosphate (PIP3), a second messenger that is produced after activation of PIP3 kinase in response to ligation of several growth factor receptors, including IGF-1. PIP3 activates the protein kinase AKT. AKT is signaling results in inhibition of apoptosis in response to a variety of signals and to increased cell proliferation [67].

In assessing the relationship of PTEN deletion with the TMPRSS2-ERG fusion, two independent groups found that patients with neither lesion had a favorable prognosis $[63$, 68].

Other markers tested in combination with PTEN loss for prognostic information include tumor protein p27 gene loss [69], hemoxygenase-1 over-expression [70], and HER2/3 overexpression [71]. A four-protein signature, as assessed by immunohistochemical staining for PTEN in combination with a subset of proteins involved in tumor growth factor-b signaling: SMAD4, cyclin D1, and SPP1, were found to predict biochemical recurrence significantly better than Gleason score alone [72]. The most promising pathway in which this is likely to be employed in the near future is the PTEN/PI3K pathway as a number of clinical trials using inhibitors of this pathway in development or underway in $\mathrm{PCa}$ [73].

Thus, the measurement of PTEN protein levels and downstream targets of AKT in prostate needle biopsies may have value in the future if these trials show to be promising. It remains to be determined which combinations of events will 
provide the most reliable prognostic information to guide clinical decision making. Moreover, it has been found that PI3K and androgen receptor (AR) pathway crosstalk plays an important role in castrate resistant PCa development, with potentially important implications for PCa etiology and therapy [74].

Biomarkers associated with castration resistant $\mathrm{PCa}$ and drug resistance. Currently, the main treatment option for men with advanced $\mathrm{PCa}$ is hormone therapy. It was described by Huggins and Hodges in 1941, and revealed that removing androgens could inhibit the progression of $\mathrm{PCa}$ [75]. Despite the initial response to androgen deprivation for most men, the disease typically progresses to a castration-resistant $\mathrm{PCa}$ (CRPCa) state within 18 to 24 months [76]. The development of resistance to hormonal intervention and why the disease progresses is not fully understood, although some mechanisms have been demonstrated, with the majority focusing on the continued androgen receptor (AR) activity in addition to TMPRSS2/ERG fusion, PTEN, Nkx3.1, and EGR1.

Although the exact mechanism underlying the progression of PCa remains poorly understood, two major mechanisms that result in the reactivation of the androgen axis in CRPCa have been extensively studied [77]. One is the activation of the androgen receptor (AR)-mediated signaling pathway either by the amplification, overexpression or mutations of the AR [78, 79]. The other mechanism mediates intratumoral androgen synthesis, involving either the de novo synthesis of AR ligands from cholesterol or the increased conversion of adrenal androgens (e.g., dehydroepiandrosterone or $\Delta 4$-Adione) to active androgens $[80,81]$.

As the disease progresses, the CRPCa ultimately metastasizes (mCRPCa). Patients with $\mathrm{mCRPCa}$ have a poor prognosis and a predicted survival rate is fewer than 2 years from the initial time of progression [82, 83]. Currently, mCRPCa remains incurable, and many treatment options are palliative in nature.

Docetaxel was the first therapy to provide improved survival rates to patients with mCRPCa. However, many patients develop resistance [84]. To combat this issue, 5 new agents have received approval by the US Food and Drug Administration (FDA) to treat mCRPCa since 2010 (abiraterone acetate, enzalutamide, cabazitaxel, radium-223, and sipuleucel-T) [85].

Docetaxel is currently the first-line treatment for patients with CRPCa offering some improvement in overall survival in comparison to other anti-cancer agents. Unfortunately, many patients either do not respond or initially respond but then relapse [86].

AKR1C3. Based on the new theory of intratumoral androgen synthesis in PCa cells, AKR1C3 was found to play a pivotal role in the synthesis of testosterone $(\mathrm{T})$ and dihydrotestosterone (DHT). In vitro experiments have shown that AKR1C3 is up-regulated in PCa cells as a survival adaptation in response to T/DHT deprivation [87]. The overexpression of AKR1C3 was found to increase the intracellular synthesis of $\mathrm{T}$ from 4-androstene-3,17-dione in CaP cells and resulted in resistance to the 5a-reductase inhibitor finasteride [88]. Several studies have reported low or undetectable levels of AKR1C3 in normal prostate epithelia, whereas elevated AKR1C3 levels have been found in localized, advanced or recurrent PCa and CRPCa $[89,90]$.

Enzalutamide is an androgen-receptor-signaling inhibitor which is distinct from the currently available antiandrogen agents in that it inhibits nuclear translocation of the androgen receptor, DNA binding, and coactivator recruitment. It also has a greater affinity for the receptor, induces tumor shrinkage in xenograft models (in which conventional agents only retard growth), and has no known agonistic effects $[91,92]$. It has been demonstrated that it prolongs survival after first line PCa chemotherapy, and became the second line therapy in mCRPCa treatment [93]. Recently, it has been suggested that AKR1C3 activation is a critical resistance mechanism associated with enzalutamide resistance, targeting intracrine androgens and AKR1C3 will overcome enzalutamide resistance and improve survival of advanced PCa patients. Overexpression of AKR1C3 confers resistance to enzalutamide [94]. It can be assumed, that AKR1C3 overexpression could serve as useful biomarker signalling enzalutamide resistance.

AR-V7. It has been recently described, that mRNA expression of a particular AR splice variant-7 (AR-V7), in circulating tumor cells (CTCs) from mCRPC patients may be associated with resistance to enzalutamide and abiraterone. AR splice variants are constitutively active isoforms of the AR that lack the ligand-binding domain yet retain their transcriptional activity in a ligand-independent fashion. Of these, AR variant- 7 may be the most important, and has been implicated in primary resistance to abiraterone and enzalutamide in men with advanced $\mathrm{PCa}$, suggesting its potential as biomarker for predicting treatment response in CRPCa [95]. Furthermore, some authors suggest that protein AR-V7 levels in primary tumors can be used as a predictive marker for the development of CRPCa and as a prognostic factor in CRPCa patients [96].

\section{Conclusions and perspectives}

There is an urgent need for novel biomarkers for assessing $\mathrm{PCa}$ diagnosis and prognosis, due to the highly variable natural history of PCa. Recently used markers cannot reliably distinguish the potentially life-threatening cancer from insignificant cancer. The identification of novel molecular and immunohistochemical methods enabled the identification of potential biomarkers in relation to prognosis. Numerous promising markers and approaches have been identified and used (loss of PTEN, fusion of genes TMPRSS2 ERG and ETV1, GWAS, next generation sequencing, combination of "traditional“ markers with novel biomarkers, etc.).

In addition, attempts to identify cancers with different response to hormonal therapy have been used. The common feature of most current studies is their lack of prospectivity, 
limited number of patients and have to be verified in larger prospective studies. However, some of these markers may be translated into clinical practice in future and can help to assess prognosis of PCa more accurately.

Acknowledgements: The presented study was supported by grant VEGA No. 1/1250/12.

\section{References}

[1] JEMAL A, SIEGEL R, WARD E, HAO Y, XU J, et al. Cancer statistics. Cancer J Clin 2009; 59: 225-249. http://dx.doi. org/10.3322/caac.20006

[2] GANDAGLIA G, SUN M, POPA I, SCHIFFMANN J, ABDOLLAH F, et al. The impact of androgen-deprivation therapy (ADT) on the risk of cardiovascular (CV) events in patients with non-metastatic prostate cancer: a populationbased study. BJU international 2014; 114: E82-9. http://dx.doi. org/10.1111/bju.12732

[3] ROAYAEI M, GHASEMI S. Effect of androgen deprivation therapy on cardiovascular risk factors in prostate cancer. J Res Med Sci. 2013; 18: 580-2.

[4] ALBERTSEN PC, KLOTZ L, TOMBAL B, GRADY J, OLESEN TK, et al. Cardiovascular morbidity associated with gonadotropin releasing hormone agonists and an antagonist. Eur Urol. 2014; 65: 565-73. http://dx.doi.org/10.1016/j. eururo.2013.10.032

[5] YONG C, ONUKWUGHA E, MULLINS CD. Clinical and economic burden of bone metastasis and skeletal-related events in prostate cancer. Curr Opin Oncol. 2014; 26: 274-83. http://dx.doi.org/10.1097/CCO.0000000000000071

[6] MCKAY RR, TAPLIN ME, CHOUEIRI TK. Optimizing bone health and minimizing skeletal morbidity in men with prostate cancer. Hematol Oncol Clin North Am. 2013; 27: 1261-83. http://dx.doi.org/10.1016/j.hoc.2013.08.009

[7] HUMPHREY PA. Gleason grading and prognostic factors in carcinoma of the prostate. Mod Pathol. 2004; 17: 292-306. http://dx.doi.org/10.1038/modpathol.3800054

[8] BLUTE ML, BERGSTRALH EJ, IOCCA A, SCHERER B, ZINCKE H. Use of Gleason score, prostate specific antigen, seminal vesicle and margin status to predict biochemical failure after radical prostatectomy. J Urol. 2001; 165: 119-25. http://dx.doi.org/10.1097/00005392-200101000-00030

[9] BOSTWICK DG, GRIGNON DJ, HAMMOND ME, AMIN $\mathrm{MB}, \mathrm{COHEN} \mathrm{M}$, et al. Prognostic factors in prostate cancer: College of American Pathologists Consensus Statement 1999. Arch Pathol Lab Med. 2000; 124: 995-1000.

[10] EPSTEIN JI, AMIN M, BOCCON-GIBOD L, EGEVAD L, HUMPHREY PA, et al. Prognostic factors and reporting of prostate carcinoma in radical prostatectomy and pelvic lymphadenectomy specimens. Scand J Urol Nephrol Suppl. 2005, 34-63. http://dx.doi.org/10.1080/03008880510030932

[11] MANOLIO TA. Genomewide association studies and assessment of the risk of disease. N Engl J Med 2010; 363: 166-76. http://dx.doi.org/10.1056/NEJMra0905980

[12] JIANG W, FREIDIN B, SIMON R. Biomarker-adaptive threshold design: a procedure for evaluating treatment with possible biomarker-defined subset effect. J Natl Cancer Inst. 2007; 99: 1036-43. http://dx.doi.org/10.1093/jnci/ djm022

[13] MACCONAILL LE, GARRAWAY LA. Clinical implications of the cancer genome. J Clin Oncol. 2010; 28: 5219-28. http:// dx.doi.org/10.1200/JCO.2009.27.4944

[14] NELSON WG, DE MARZO AM, ISAACS WB. Prostate cancer. N Engl J Med. 2003; 349: 366-81. http://dx.doi. org/10.1056/NEJMra021562

[15] ZHENG SL, SUN J, WIKLUND F, SMITH S, STATTIN P, et al. Cumulative association of 5 genetic variants with prostate cancer. N Engl J Med. 2008; 358: 910-9. http://dx.doi. org/10.1056/NEJMoa075819

[16] HANAHAN D, WEINBERG RA. The hallmarks of cancer. Cell. 2000; 100(1): 57-70. http://dx.doi.org/10.1016/S00928674(00)81683-9

[17] FEBBO PG. Genomic approaches to outcome prediction in prostate cancer. Cancer 2009; 115: 3046-57. http://dx.doi. org/10.1002/cncr.24350

[18] BIOMARKERS DEFINITIONS WORKING GROUP. Biomarkers and surrogate endpoints: Preferred definitions and conceptual framework. Clin Pharmacol Ther. 2001; 69: 89-95. http://dx.doi.org/10.1067/mcp.2001.113989

[19] NATIONAL CANCER INSTITUTE. Dictionary of Cancer Terms. http: //www.cancer.gov/dictionary/ ?searchTxt=biomarker.

[20] COX TM. Biomarkers in lysosomal storage diseases: a review. Acta Paediatr Suppl. 2005; 94: 39-42. http://dx.doi. org/10.1080/08035320510028085

[21] BIOMARKERS DEFINITIONS WORKING GROUP. Cancer biomarkers: a systems approach. Clin Pharmacol Ther. 2001; 69: 89-95.

[22] BEUTEN J, GELFOND JA, MARTINEZ-FIERRO ML, WELDON KS, CRANDALL AC, et al. Association of chromosome $8 \mathrm{q}$ variants with prostate cancer risk in Caucasian and Hispanic men. Carcinogenesis. 2009; 30: 1372-9. http:// dx.doi.org/10.1093/carcin/bgp148

[23] ROBBINS C, TORRES JB, HOOKER S, BONILLA C, HERNANDEZ W, et al. Confirmation study of prostate cancer risk variants at 8q24 in African Americans identifies a novel risk locus. Genome Res. 2007; 17: 1717-22. http://dx.doi. org/10.1101/gr.6782707

[24] EELES RA, OLAMA AA, BENLLOCH S, SAUNDERS EJ, LEONGAMORNLERT DA, et al. Identification of seven new prostate cancer susceptibility loci through a genome-wide association study. Nat Genet. 2013; 45: 385-91, 391e1-2.

[25] CLARKE RA, SCHIRRA HJ, CATTO JW, LAVIN MF, GARDINER RA. Markers for detection of prostate cancer. Cancers (Basel). 2010; 2: 1125-54. http://dx.doi.org/10.3390/ cancers2021125

[26] SALAGIERSKI M, SCHALKEN JA. Molecular diagnosis of prostate cancer: PCA3 and TMPRSS2: ERG gene fusion. J Urol. 2012; 187: 795-801. http://dx.doi.org/10.1016/j. juro.2011.10.133

[27] TOSOIAN JJ, LOEB S, KETTERMANN A, LANDIS P, ELLIOT DJ, et al. Accuracy of PCA3 measurement in predicting short-term biopsy progression in an active surveillance pro- 
gram. J Urol. 2010; 183: 534-8. http://dx.doi.org/10.1016/j. juro.2009.10.003

[28] VAN GILS MP, HESSELS D, VAN HOOIJ O, JANNINK SA, PEELEN WP, et al. The time-resolved fluorescencebased PCA3 test on urinary sediments after digital rectal examination; a Dutch multicenter validation of the diagnostic performance. Clin Cancer Res. 2007; 13: 939-43. http://dx.doi. org/10.1158/1078-0432.CCR-06-2679

[29] MARKS LS, FRADET Y, DERAS IL, BLASE A, MATHIS J, et al. PCA3 molecular urine assay for prostate cancer in men undergoing repeat biopsy. Urology. 2007; 69: 532-5. http:// dx.doi.org/10.1016/j.urology.2006.12.014

[30] HESSELS D, SMIT FP, VERHAEGH GW, WITJES JA, CORNEL EB, et al. Detection of TMPRSS2-ERG fusion transcripts and prostate cancer antigen 3 in urinary sediments may improve diagnosis of prostate cancer. Clin Cancer Res. 2007; 13: 5103-8. http://dx.doi.org/10.1158/1078-0432.CCR-07-0700

[31] SALAMI SS, SCHMIDT F, LAXMAN B, REGAN MM, RICKMAN DS, et al. Combining urinary detection of TMPRSS2: ERG and PCA3 with serum PSA to predict diagnosis of prostate cancer. Urol Oncol. 2013; 31: 566-71. http:// dx.doi.org/10.1016/j.urolonc.2011.04.001

[32] CORNU JN, CANCEL-TASSIN G, EGROT C, GAFFORY C, HAAB F, et al. Urine TMPRSS2: ERG fusion transcript integrated with PCA3 score, genotyping, and biological features are correlated to the results of prostatic biopsies in men at risk of prostate cancer. Prostate. 2013; 73: 242-9. http:// dx.doi.org/10.1002/pros.22563

[33] LEMAN ES, CANNON GW, TROCK BJ, SOKOLL LJ, CHAN DW, et al. EPCA-2: a highly specific serum marker for prostate cancer. Urology. 2007; 69: 714-20. http://dx.doi. org/10.1016/j.urology.2007.01.097

[34] WITT H, LUCK W, HENNIES HC, CLASSEN M, KAGE $A$, et al. Mutations in the gene encoding the serine protease inhibitor, Kazal type 1, are associated with chronic pancreatitis. Nat Genet. 2000; 25: 213-6. http://dx.doi. org/10.1038/76088

[35] BHATIA E, CHOUDHURI G, SIKORA SS, LANDT O, KAGE A, et al. Tropical calcific pancreatitis: strong association with SPINK1 trypsin inhibitor mutations. Gastroenterology. 2002; 123: 1020-5. http://dx.doi.org/10.1053/ gast.2002.36028

[36] LAXMAN B, MORRIS DS, YU J, SIDDIQUI J, CAO J, et al. A first-generation multiplex biomarker analysis of urine for the early detection of prostate cancer. Cancer Res. 2008; 68: 645-9. http://dx.doi.org/10.1158/0008-5472.CAN-07-3224

[37] FLAVIN R, PETTERSSON A, HENDRICKSON WK, FIORENTINO M, FINN S, et al. SPINK1 Protein Expression and Prostate Cancer Progression. Clin Cancer Res. 2014; 20 : 4904-11. http://dx.doi.org/10.1158/1078-0432.CCR-13-1341

[38] KUEFER R, VARAMBALLY S, ZHOU M, LUCAS PC, LOEFFLER M, et al. Alpha-methylacyl-CoA racemase: expression levels of this novel cancer biomarker depend on tumor differentiation. Am J Pathol. 2002; 161: 841-8. http:// dx.doi.org/10.1016/S0002-9440(10)64244-7

[39] ZHA S, FERDINANDUSSE S, DENIS S, WANDERS RJ, EWING CM, et al. Alpha-methylacyl-CoA racemase as an androgen-independent growth modifier in prostate cancer. Cancer Res. 2003; 63: 7365-76.

[40] JIANG Z, WU CL, WODA BA, ICZKOWSKI KA, CHU PG, et al. Alpha-methylacyl-CoA racemase: a multi-institutional study of a new prostate cancer marker. Histopathology. 2004; 45: 218-25. http://dx.doi.org/10.1111/j.1365-2559 2004.01930.x

[41] ROGERS CG, YAN G, ZHA S, GONZALGO ML, ISAACS WB, et al. Prostate cancer detection on urinalysis for alpha methylacyl coenzyme A racemase protein. J Urol. 2004; 172: 1501-3. http://dx.doi.org/10.1097/01. ju.0000137659.53129.14

[42] SREEKUMAR A, LAXMAN B, RHODES DR, BHAGAVATHULA S, HARWOOD J, et al. Humoral immune response to alpha-methylacyl-CoA racemase and prostate cancer. J Natl Cancer Inst. 2004; 96: 834-43. http://dx.doi. org/10.1093/jnci/djh145

[43] FESTUCCIA C, GRAVINA GL, MANCINI A, MUZI P, CESARE ED, et al. Trifluoroibuprofen inhibits a-methylacyl coenzyme A racemase (AMACR/P504S), reduces cancer cell proliferation and inhibits in vivo tumor growth in aggressive prostate cancer models. Anticancer Agents Med Chem. 2014; 14: 1031-41. http://dx.doi.org/10.2174/18715206146661403 $\underline{27152607}$

[44] HAYES JD, PULFORD DJ. The glutathione S-transferase supergene family: regulation of GST and the contribution of the isoenzyme to cancer chemoprotection and drug resistance. Crit Rev Biochem Mol Biol. 1995; 30: 445-600. http://dx.doi. org/10.3109/10409239509083491

[45] HARDEN SV, GUO Z, EPSTEIN JI, SIDRANSKY D. Quantitative GSTP1 methylation clearly distinguishes benign prostatic tissue and limited prostate adenocarcinoma. J Urol. 2003; 169: 1138-42. http://dx.doi.org/10.1097/01. ju.0000049627.90307.4d

[46] LEE WH, MORTON RA, EPSTEIN JI, BROOKS JD, CAMPBELL PA, et al. Cytidine methylation of regulatory sequences near the pi-class glutathione S-transferase gene accompanies human prostatic carcinogenesis. Proc Natl Acad Sci U S A. 1994; 91: 11733-7. http://dx.doi.org/10.1073/ pnas.91.24.11733

[47] CHEN H, PONG RC, WANG Z, HSIEH JT. Differential regulation of the human gene DAB2IP in normal and malignant prostatic epithelia: cloning and characterization. Genomics. 2002; 79: 573-81. http://dx.doi.org/10.1006/geno.2002.6739

[48] CHEN H, TOYOOKA S, GAZDAR AF, HSIEH JT. Epigenetic regulation of a novel tumor suppressor gene (hDAB2IP) in prostate cancer cell lines. J Biol Chem. 2003; 278: 3121-30. http://dx.doi.org/10.1074/jbc.M208230200

[49] CHEN H, TU SW, HSIEH JT. Down-regulation of human DAB2IP gene expression mediated by polycomb Ezh2 complex and histone deacetylase in prostate cancer. J Biol Chem. 2005; 280: 22437-44. http://dx.doi.org/10.1074/jbc. M501379200

[50] CHEN H, TOYOOKA S, GAZDAR AF, HSIEH JT. Epigenetic regulation of a novel tumor suppressor gene (hDAB2IP) in prostate cancer cell lines. J Biol Chem. 2003; 278: 3121-30. http://dx.doi.org/10.1074/jbc.M208230200 
[51] DUGGAN D, ZHENG SL, KNOWLTON M, BENITEZ D, DIMITROV L, et al. Two genome-wide association studies of aggressive prostate cancer implicate putative prostate tumor suppressor gene DAB2IP. J Natl Cancer Inst. 2007; 99: 1836-44. http://dx.doi.org/10.1093/jnci/djm250

[52] BHATIA-GAUR R, DONJACOUR AA, SCIAVOLINO PJ, KIM M, DESAI N, et al. Roles for Nkx3.1 in prostate development and cancer. Genes Dev. 1999; 13: 966-77. http://dx.doi. org/10.1101/gad.13.8.966

[53] BOWEN C, BUBENDORF L, VOELLER HJ, SLACK R, WILLI N, et al. Loss of NKX3.1 expression in human prostate cancers correlates with tumor progression. Cancer Res. 2000; 60: 6111-5.

[54] OUYANG X, DEWEESE TL, NELSON WG, ABATE-SHEN C. Loss-of-function of Nkx3.1 promotes increased oxidative damage in prostate carcinogenesis. Cancer Res. 2005; 65: 6773-9. http://dx.doi.org/10.1158/0008-5472.CAN-05-1948

[55] ALI TZ, EPTEIN JI, BEIBERICH CJ, DE MARZO AM. NKX3.1 as a new tissue marker of prostatic adenocarcinoma. Laboratory Investigation. 2006; 86: 128.

[56] BARNABAS N, XU L, SAVERA A, HOU Z, BARRACK ER. Chromosome 8 markers of metastatic prostate cancer in African American men: Gain of the MIR151 gene and loss of the NKX3-1 gene. Prostate. 2011; 71: 857-71. http://dx.doi. org/10.1002/pros.21302

[57] WILSON S, GREER B, HOOPER J, ZIJLSTRA A, WALKER $\mathrm{B}$, et al. The membrane-anchored serine protease, TMPRSS2, activates PAR-2 in prostate cancer cells. Biochem J. 2005; 388: 967-72. http://dx.doi.org/10.1042/B]20041066

[58] KUMAR-SINHA C, TOMLINS SA, CHINNAIYAN AM. Recurrent gene fusions in prostate cancer. Nat Rev Cancer. 2008; 8: 497-511. http://dx.doi.org/10.1038/nrc2402

[59] MWAMUKONDA K, CHEN Y, RAVINDRANATH L, FURUSATO B, HU Y, et al. Quantitative expression of TMPRSS2 transcript in prostate tumor cells reflects TMPRSS2-ERG fusion status. Prostate Cancer Prostatic Dis. 2010; 13: 47-51. http://dx.doi.org/10.1038/pcan.2009.28

[60] CAI C, WANG H, XU Y, CHEN S, BALK SP. Reactivation of androgen receptor-regulated TMPRSS2: ERG gene expression in castration-resistant prostate cancer. Cancer Res. 2009; 69: 6027-32. http://dx.doi.org/10.1158/0008-5472.CAN-09$\underline{0395}$

[61] TOMLINS SA, RHODES DR, PERNER S, DHANASEKARAN SM, MEHRA R, et al. Recurrent fusion of TMPRSS2 and ETS transcription factor genes in prostate cancer. Science. 2005; 310 : 644-8. http://dx.doi.org/10.1126/science.1117679

[62] FURUSATO B, GAO CL, RAVINDRANATH L, CHEN Y, CULLEN J, et al. Mapping of TMPRSS2-ERG fusions in the context of multi-focal prostate cancer. Mod Pathol. 2008; 21: $67-75$

[63] REID AH, ATTARD G, AMBROISINE L, FISHER G, KOVACS G, et al. Molecular characterisation of ERG, ETV1 and PTEN gene loci identifies patients at low and high risk of death from prostate cancer. Br J Cancer. 2010; 102: 678-84. http:// dx.doi.org/10.1038/sj.bjc.6605554

[64] MEHRA R, TOMLINS SA, YU J, CAO X, WANG L, et al. Characterization of TMPRSS2-ETS gene aberrations in androgen-independent metastatic prostate cancer. Cancer Res. 2008; 68: 3584-90. http://dx.doi.org/10.1158/0008-5472. CAN-07-6154

[65] MACGROGAN D, BOOKSTEIN R.. Tumor suppressor genes in prostate cancer. Semin Cancer Biol. 1997; 8: 11-9. http:// dx.doi.org/10.1006/scbi.1997.0048

[66] MCMENAMIN ME, SOUNG P, PERERA S, KAPLAN I, LODA M, et al. Loss of PTEN expression in paraffinembedded primary prostate cancer correlates with high Gleason score and advanced stage. Cancer Res. 1999; 59: 4291-6.

[67] VIVANCO I, SAWYERS CL. The phosphatidylinositol 3-Kinase AKT pathway in human cancer. Nat Rev Cancer. 2002; 2: 489-501. http://dx.doi.org/10.1038/nrc839

[68] YOSHIMOTO M, JOSHUA AM, CUNHA IW, COUDRY RA, FONSECA FP, et al. Absence of TMPRSS2: ERG fusions and PTEN losses in prostate cancer is associated with a favorable outcome. Mod Pathol. 2008; 21: 1451-60. http://dx.doi. org/10.1038/modpathol.2008.96

[69] HALVORSEN OJ, HAUKAAS SA, AKSLEN LA. Combined loss of PTEN and p27 expression is associated with tumor cell proliferation by Ki-67 and increased risk of recurrent disease in localized prostate cancer. Clin Cancer Res. 2003; 9: 1474-9.

[70] LI Y, SU J, DINGZHANG X, ZHANG J, YOSHIMOTO M, et al. PTEN deletion and heme oxygenase-1 overexpression cooperate in prostate cancer progression and are associatedwith adverse clinical outcome. J Pathol. 2011; 224: 90-100. http://dx.doi.org/10.1002/path.2855

[71] AHMAD I, PATEL R, SINGH LB, NIXON C, SEYWRIGHT $\mathrm{M}$, et al. HER2 overcomes PTEN (loss)- induced senescence to cause aggressive prostate cancer. Proc Natl Acad Sci U S A. 2011; 108: 16392-7. http://dx.doi.org/10.1073/ pnas. 1101263108

[72] DING Z, WU CJ, CHU GC, XIAO Y, HO D, et al. SMAD4dependent barrier constrains prostate cancer growth and metastatic progression. Nature. 2011; 470: 269-73. http:// dx.doi.org/10.1038/nature09677

[73] THOMAS GV, HORVATH S, SMITH BL, CROSBY K, LEBEL LA, et al. Antibody-based profiling of the phosphoinositide 3-kinase pathway in clinical prostate cancer. Clin Cancer Res. 2004; 10: 8351-6. http://dx.doi.org/10.1158/1078-0432.CCR04-0130

[74] MULHOLLAND DJ, TRAN LM, LI Y, CAI H, MORIM A, et al. Cell autonomous role of PTEN in regulating castrationresistant prostate cancer growth. Cancer Cell. 2011; 19: 792-804. http://dx.doi.org/10.1016/j.ccr.2011.05.006

[75] HUGGINS C, HODGES CV. Studies on prostatic cancer. I. The effect of castration, of estrogen and of androgen injection on serum phosphatases in metastatic carcinoma of the prostate. Cancer Res. 1941; 1: 293-297.

[76] SERUGA B, OCANA A, TANNOCK IF. Drug resistance in metastatic castration-resistant prostate cancer. Nat Rev Clin Oncol. 2011; 8: 12-23. http://dx.doi.org/10.1038/ nrclinonc. 2010.136

[77] KNUDSEN KE, PENNING TM: Partners in crime: deregulation of AR activity and androgen synthesis in prostate cancer. 
Trends Endocrinol Metab. 2010; 21: 315-324. http://dx.doi. org/10.1016/j.tem.2010.01.002

[78] LAPOUGE G, MARCIAS G, ERDMANN E, KESSLER P, CRUCHANT M, et al. Specific properties of a C-terminal truncated androgen receptor detected in hormone refractory prostate cancer. Adv Exp Med Biol. 2008; 617: 529-534. http:// dx.doi.org/10.1007/978-0-387-69080-3 53

[79] REDDY GP, BARRACK ER, DOU QP, MENON M, PELLEY $\mathrm{R}$, et al. Regulatory processes affecting androgen receptor expression, stability, and function: potential targets to treat hormone-refractory prostate cancer. J Cell Biochem. 2006; 98: 1408-1423. http://dx.doi.org/10.1002/jcb.20927

[80] HOFLAND J, VAN WEERDEN WM, DITS NF, STEENBERGEN J, VAN LEENDERS GJ, et al. Evidence of limited contributions for intratumoral steroidogenesis in prostate cancer. Cancer Res. 2010; 70: 1256-1264. http://dx.doi. org/10.1158/0008-5472.CAN-09-2092

[81] PFEIFFER MJ, SMIT FP, SEDELAAR JP, SCHALKEN JA. Steroidogenic enzymes and stem cell markers are upregulated during androgen deprivation in prostate cancer. Mol Med. 2011; 17: 657-664. http://dx.doi.org/10.2119/ molmed.2010.00143

[82] HUANG X, CHAU CH, FIGG WD. Challenges to improved therapeutics for metastatic castrate resistant prostate cancer: from recent successes and failures. J Hematol Oncol. 2012; 5 : 35. http://dx.doi.org/10.1186/1756-8722-5-35

[83] AMERICAN CANCER SOCIETY. What are the key statistics about prostate cancer? http: //www.cancer.org/cancer/ prostatecancer/detailedguide/prostate-cancer-key-statistics. Accessed October 15, 2014.

[84] PETRYLAK DP, TANGEN CM, HUSSAIN MH, LARA PN JR, JONES JA, et al. Docetaxel and estramustine compared with mitoxantrone and prednisone for advanced refractory prostate cancer. N Engl J Med. 2004; 351: 1513-1520. http:// dx.doi.org/10.1056/NEJMoa041318

[85] AGARWAL N, DI LORENZO G, SONPAVDE G, BELLMUNT J. New agents for prostate cancer. Ann Oncol. 2014; 25: 1700-1709. http://dx.doi.org/10.1093/annonc/mdu038

[86] BERTHOLD DR, STERNBERG CN, TANNOCK IF. Management of advanced prostate cancer after first-line chemotherapy. J Clin Oncol. 2005; 23: 8247-8252. http:// dx.doi.org/10.1200/JCO.2005.03.1435

[87] PFEIFFER MJ, SMIT FP, SEDELAAR JP, SCHALKEN JA. Steroidogenic enzymes and stem cell markers are up- regulated during androgen deprivation in prostate cancer. Mol Med. 2011; 17: 657-664. http://dx.doi.org/10.2119/ molmed.2010.00143

[88] BYRNS MC, MINDNICH R, DUAN L, PENNING TM. Overexpression of aldo-ketoreductase 1C3 (AKR1C3) in LNCaP cells diverts androgen metabolism towards testosterone resulting in resistance to the 5alpha-reductase inhibitor finasteride. J Steroid Biochem Mol Biol. 2012; 130: 7-15. http:// dx.doi.org/10.1016/j.jsbmb.2011.12.012

[89] FUNG KM, SAMARA EN, WONG C, METWALLI A, KRLIN $\mathrm{R}$, et al. Increased expression of type 2 3alpha-hydroxysteroid dehydrogenase/type 5 17beta-hydroxysteroid dehydrogenase (AKR1C3) and its relationship with androgen receptor in prostate carcinoma. Endocr Relat Cancer. 2006; 13: 169-180. http://dx.doi.org/10.1677/erc.1.01048

[90] NAKAMURA Y, SUZUKI T, NAKABAYASHI M, ENDOH $\mathrm{M}$, SAKAMOTO K, et al. In situ androgen producing enzymes in human prostate cancer. Endocr Relat Cancer. 2005; 12: 101-107. http://dx.doi.org/10.1677/erc.1.00914

[91] JUNG ME, OUK S, YOO D, SAWYERS CL, CHEN C, et al. Structure-activity relationship for thiohydantoin androgen receptor antagonists for castration-resistant prostate cancer (CRPC). J Med Chem. 2010; 53: 2779-2796. http://dx.doi. org/10.1021/jm901488g

[92] TRAN C, OUK S, CLEGG NJ, CHEN Y, WATSON PA, et al. Development of a second-generation antiandrogen for treatment of advanced prostate cancer. Science 2009; 324: 787-790. http://dx.doi.org/10.1126/science.1168175

[93] SCHER H, FIZAZI K, SAAD F, TAPLIN M, STERNBERG C, et al. Increased survival with enzalutamide in prostate cancer after chemotherapy. N Engl J Med. 2012; 367: 1187-1197. http://dx.doi.org/10.1056/NEJMoa1207506

[94] LIU C, LOU W, ZHU Y, YANG JC, NATIMINTY N, et al. Intracrine androgens and AKR1C3 activation confer resistance to enzalutamide in prostate cancer. Cancer Res. 2015 (in press). http://dx.doi.org/10.1158/0008-5472.CAN-14-3080

[95] ANTONARAKIS ES, LU C, WANG H, LUBER B, NAKAZAWA $\mathrm{M}$, et al. AR-V7 and resistance to enzalutamide and abiraterone in prostate cancer. N Engl J Med. 2014; 371: 1028-38. http://dx.doi.org/10.1056/NEJMoa1315815

[96] QU Y, DAI B, YE D, KONG Y, CHANG K, et al. Constitutively active AR-V7 plays an essential role in the development and progression of castration-resistant prostate cancer. Sci Rep. 2015; 5: 7654. http://dx.doi.org/10.1038/srep07654 